\title{
The Image of Women in Eastern and Western Epic literature: Shahnameh and Odyssey
}

\author{
Fatemeh Sadat Basirizadeh $^{1}$, Narges Raoufzadeh ${ }^{2}$, Shiva Zaheri Birgani ${ }^{3}$ \\ ${ }^{1}$ Department of English Language and Literature, Science and Research Branch, Islamic Azad University, \\ Tehran, Iran. \\ ${ }^{2}$ Department of English Language and Literature, Science and Research Branch, Islamic Azad University, \\ Tehran, Iran. \\ ${ }^{3}$ Islamic Azad University, Masjed Soleyman, Khuzestan Province, Iran \\ nbasiri2002@yahoo.com
}

\begin{abstract}
:
The research examines two epics, one from the East and one from the West with regards to the question of woman and her images in early epic literature. The epics were selected from the literature. The epics were selected from the literature of two cultures, both of which, in different historical periods produced the most advanced civilizations of their time. The Persian epic, The Shahnameh (the book of Kings) was tooted in the ancient IndoIranian pagan as well as Zoroastrian traditions, an epic of approximately 60,000 couplets rewritten in the tenth century A. D. in the final, completed from which has reached us today. The Greek exemplar was the odyssey of Homer, epic with which Greek literature begins and widely influences not only the later periods of Greek literature but also the entire Western literature; this epic is also widely known in the East. Central to our study of The Shahnameh and Homeric epics were the themes of dynamism, the individuality of characters and their struggles in the epic world, the resourcefulness of the human mind ascribed to them, the subject of human crises, and irony, all of which are deep-seated components marking the central literary qualities of these epics. Women are indispensable in the early epics of both traditions and more often than not highly regarded by epic heroes in general and the narrators of the stories in particular. In both Eastern and Western example the structure split the female image in two opposite directions: one force is represented by exalted, praiseworthy, and positive images which also endow the women of The Shahnameh and the Homeric poems with powerful characteristics.
\end{abstract}

Keywords

misogyny; feminism;

women; identity

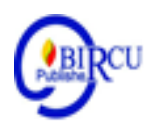

\section{Introduction}

Giving importance to common human affliction is the secret of maintaining oral and written literary works of any nation. The reason is that topics such as ill-temper, goodtemper, hatred, love, chastity, honesty, hypocrisy, envy, anger and greed have been and will be the subjects of all generations and eras and no generation has been able to ignore, abandon or lose them entirely. On the other hand, the way of expressing and creative structure as well as the legendary, fictional and mythical structure of these stories and statements have not made a difference among them. So, dealing with common afflictions with common subjective language in various literary forms shows the unity and uniformity which is the secret of maintaining; both " Iliad and Odyssey of Homer" and Ferdowsi's 
Shahnameh. Shahnameh stories include human life and concerns of the era in the form of stories, myths, and legends

Basirizadeh in his article mentions that, "In de Beauvoir's view if women really want a status, they should deconstruct the structures of the masculine society and present their own definition of feminity. This definition would be the proof of woman's presence and existence counter-intuitive to masculine canon of knowledge in power"'(2).

The purpose of this paper is to provide an analysis of the roles and images of women as found in the texts of three major epics from the early literature of the East and West. The Eastern exemplar will be the Persian epic The Shahnameh (The Book of Kings), rooted in the ancient Indo-Iranian pagan and Zoroastrian traditions, an epic of approximately 60,000 couplets, rewritten in the tenth century A.D. The Western exemplars will be the two major Greek epics of Homer, the Iliad and the Odyssey. In both the Persian and Greek cultures which produced highly refined civilizations at different historical periods, misogyny followed the periods of the epics, it did not precede them. The epics demonstrate no hatred or insincerity toward women; instead women are indispensable in these early epics and, more often than not, highly regarded by the heroes of the epics as well as their narrators.

Noldeke's works and many of his opinions have been perpetuated, especially his views on the women of The Shahnameh, the Iliad, and the Odyssey, typical of which is the following statement translated from the original German:

In The Shahnameh women do not play a very active role. They appear only as the object of desire or love .... Such figures as Penelope, Andromache, and Nausicaa, who in their pure womanhood are equal to men cannot be found in the Persian epic. (59)

\section{Discussion}

\subsection{The Persian Epic: The Shahnameh, Ferdowsi, and Misogyny}

Our main point concerning Noldeke's comparative observation is: Noldeke has established a view of The Shahnameh which remains influential: that Ferdowsi's women characters are insipid as compared to those in Homer. This is hardly self- evident neither poet paints insipid characters but, rather, paradoxical characters who are women of personal substance limited by social constraints. To put it differently, while there exists no sustained misogyny in the texts of the epics, nor any evidence that the poets had such an attitude toward women, the characters are, nevertheless, in a paradoxical situation in which on the one hand, they possess resourcefulness of character, and on the other, they are ironically limited by social constraints inherent in the structure of each story.

\section{a. Introduction to the Epic}

The Shahnameh, the most significant epic in Persian literature, is the monumental work of the premier epic poet Ferdowsi. Accurate biographical information about the poet is nonexistent; all we know about him is based on the information extracted from the main text of the epic in which the poet gives certain dates and events of his life and his work. Ferdowsi was one of the major poets of Persian Renaissance literature of the 10th and 11th centuries A.D. The Shahnameh is a work of approximately 60,000 couplets (equivalent to approximate1y 120,000 lines in English poetry). In comparison, the Iliad of Homer contains about 16,000 lines. Other epics such as Beowulf are very short compared to this work. Norma Goodrich observes that: 
Ferdowsi has been compared to Homer, to Chaucer, to Layaman, and to the author of Beowulf epic. While all of these comparisons have some grain of truth, it seems rather that there is no work in the Western world of such length and completeness. Our epics are episodes by comparison. (109)

The Shahnameh begins at the beginning of time in the name of the Lord of soul and wisdom; it follows the creation of universe and of the world, the creation of man, the sun and the moon; it follows the succession of the Persian kings and heroes through history and ends with the fall of the Persian empire to the Mus'em Arabs toward the middle of the seventh century A.D.

The Shahnameh is composed of three major parts in which appear approximately 60 women characters. Although these characters are found in all three sections of the epic: the mythological, the legendary, and the historical part, the present detailed character analysis cannot possibly deal with all those women. My research will center on major characters in the legendary part, in which the most important characters all appear. These are characters who reflect major viewpoints about women in the world of the epic, illustrating not only ideal images in them, but also their limitations in their world. I will examine six major female characters as they appear in the text of The Shahnameh.

According to almost all feminist scholar's patriarchy refers to rule of the father in a male dominated society as a social and ideological construct which regards men as superior to women. They are of opinion that men's domination over female sexuality is central to women's subordination. In fact, man is the head of the family who controls women's sexuality, labor, production, reproduction and mobility. Moreover, the effect of patriarchy can be traced in politics, public life and economy as well as in all aspects of social, personal, psychological and sexual existence.(Raoufzadeh,60)

\section{b. Ferdowsi and Misogyny}

Ferdowsi has often been accused of being a misogynist. This accusation stems from harsh comments directly made toward women in the text of some copies of the epic that have been rewritten over the centuries. However, as we mentioned earlier these texts have been contaminated through the additions of couplets and totally irrelevant comments which suited the tastes and the views of the copiers, some of whom were poets in their own rights and were able to assimilate their additions into the main text on such example, from among too many to list here, is found in "The Story of Zal and Rudabeh.

The major female character of the story, Rudabeh, is presented most favorably and in the best possible manner that a character maybe portrayed. However, within this story there exist two irrelevant couplets which infiltrated the text of the epic in later centuries. The couplets in this story, as well as their equivalents in other episodes of the epic, contributed to the misconception of Ferdowsi's misogyny. The lines in question are:

What a good talk that woman voted Do not remember men in front of women

The woman's heart is the same demon Murderers, vote seekers

Ferdowsi is angry with women or perhaps complains that they cannot control themselves in falling in love with men. The poet's comment is a counsel especially to young girls who are more vulnerable to the demon of temptation in their hearts because their desires overpower their wisdom" (53). But the fact is that such comments are not the work of the 
poet himself and that they have been added to the text by copiers over the centuries. The example given above does not fit the context of the story which is filled with praise for Rudabeh.

The best example of Ferdowsi courtesy toward women is his own friendship with his wife and his high regard for her. The source of this informat 1 on is the poet introduction to the "Story of Bizhan and Manizheh"

\section{c. Homer and Misogyny}

In terms of comparison we have already noted Theodor Noldeke's misrepresentation of the Shahnameh female characters and the claim in his comparative judgment that "In the Shahnameh women do not play a very active role. They appear only as the object of desire or love" (59). The opinion which Noldeke has perpetuated does not reflect Ferdowsi's attitude toward women. Neither does it represent the Shahnameh women as they really are; we will see in Part II whether such a sweeping) judgment and a false coherence can, under close scrutiny, be sustained. His vision of Homeric women, however, is disparately positive: "Such figures as Penelope, Andramache, and Nausicaa, who in their pure womanhood are equal to men, cannot be found in the Persian epic" (59, emphasis mine). Implicitly, the comment may point toward, but does not develop, the conclusion that there exists no expression of misogyny in Homer. Concerning the status of female characters in Homer's poetry, at least three major scholarly positions can be singled out:

The position that women in Homer's epics do not count whatsoever. Nowhere can we find a better example than in M. 1. Finley's the World of Odysseus. In the foreword to this work Mark Van Doren confirms:

What Mr. Finley hopes to save us from is the consequence of expecting Homer's heroes to behave exactly as we think we might behave in similar circumstances, or might have behaved had we been there. There are certain things about Homer's world.... It was a world exclusively, or almost exclusively, of warriors and kings, a world where few things counted except riches, prowess, and honor It was a world primarily of men, not of women and children. Compared with Homer, Ferdowsi was in a more vulnerable position. His enthusiasts had the opportunity to alter the Ferdowsi's image not only in commentaries on his work as they did with Greek. Poet, but with access to the manuscripts of the work itself, they could easily integrate misogynist views in to the poems and give authority to statement Ferdowsi never made. (22)

\subsection{Women of the Shahnameh}

The Shahnameh represents a renaissance world view in which the representation of human condition, enthusiasm for Life in this world, active confrontation with human crises, and the glorification of the dynamic, autonomous personally, together with ethical and moral considerations, are all indispensable components. The Shahnameh 15 Composed of three major parts in which appear approx1mately 60 women characters. Rudabeh, Tahmineh, Katayun, Gurdafarid, the Nameless Mother of Siyavush, and Sudabeh are specifically endowed with dynamic individuality and powerful character.

\section{a. Rudabeh, Tahmineh and Katayun: IHappy Girls and Lamenting Mothers}

These are three very important women who, despite the uniqueness and originality of their characters, have much in common in the narrative context of the epic. 
b. Rudabeh: is a major character in the story of "Zal and Rudabeh," a popular love story which is often selected to represent Persian literature in some anthologies of world. The element of beauty-as-character-strength plays a significant role in the context of the story, not only to establish .the significance of Rudabeh, or her importance in the eyes of other characters, but also as a narrative tool in establishing character relationships. In the context of the story Rudabeh's amazing beauty is renowned in her father's kingdom and in the neighboring countries, a component which plays a central role in bringing Zal and Rudabeh together. Zal, hearing about her from one of his attendants, falls madly in love with her. The narrator adds that the description of Rudabeh's beauty wins the heart of the Iranian hero. Rudabeh s beauty and Insight t, therefore, complement her boldness. She is an Independent woman of action. Independent of her parents, she herself consult her girl-attendants about her feelings for Za1 and convinces that $\mathrm{Zal}$ is the right man for her.

Estimated mortar to boil

So it was that the temptress went quiet

The night came full of thought

Ignore the unassuming return of Hall

c. Tahmineh: is the major female character in the tragedy of "Rustam and Sohrab." This tragedy has been introduced to the English readers by James Atkinson in verse translations and by Matthew Arnold in one of his narrative poems entitled "Sohrab and Rustam.

The best passive description of this woman in the Shahnameh IS found ... when she is first Introduced to the reader in the episode of Rustam has fallen asleep at Samangan. In that episode the epic poet uses the best of his poetic talent to describe Tahmineh, while she proceeds toward Rustam's bed chamber.

Cho passed away an interest in the darkness of the night

Turn the Sirius on the wheel

Speaking came a secret

They softened in their sleep

A handful of candle holders

Come on drunk to bed

So the curtain for a month on

Chu sun shining full of color and smell

Two eyebrows and two cheekbones

Up to the high cedar deeds

His psyche was wiser than pure soul

You said it didn't benefit the soil

These lines and the couplets which reveal several qualities in Tahmineh characters much in the same as in Rudabeh, the subject of beauty as-character-strength. The first layer is Tahm1nch's extraordinary physical beauty, charm, and attraction. The second layer deals with Tahmineh's spiritual beauty which goes beyond earthly limitation and has a kind of holy connotation. Rudabeh and Tahmineh have much in common. The next immed1ate point is the explicit declaration that Tahmineh is wise.

Perhaps the most significant element in The Shahnameh is wisdom

In the name of God

Superior Casein Thoughts 
d. Katayun: plays a major role in three consecutive stories: "The Reign Luhrasp", "'The Reign of Gushtasp", and "Rustam and Esfandiyar."

A brief account of Katayun is role in the epic may be divided into two parts: Part I deals with Kahayan's early life when, as the daughter of the Caesar of Rome, she lives in her father's palace; she meets and marries Gushtasp, the Prince of Iran. In Part II: she is the Queen of Iran in Gushtasp`s court and has given birth to Prince Esfandiyar. The paradigrn of Kahayan's character is a combination of characteristics, both positive and negative--prevalent in the lives of Rudabeh and Tahmineh. Indeed, the lives of Rudabeh and Tahmineh foreshadow that of Katayun. In Part I she demonstrate independence of character; she displays courage in facing an angry father and is ready to accept the consequences of her decisions; she is unpretentious, prefers inward happiness to external glitters. As an autonomous, strong character she creates a life for herself and her husband despite difficulties, and proves to be a loyal wife. In Part II she is presented as an insightful woman, wise, loving and caring mother, and above all a counselor who is also actively involved with unfolding events.

Chu hear Gashtasp with him go to Ivan Kaiser, hurry up Taft

It turned into a lull in the tiredness of sitting in the sun full of pain

They awoke to the hearts of the servants of Katayun and the worshipers of the worshipers

You all went around your porch and bought a nurse

Cho saw Gestasp from afar

Who fell asleep from the cloak

\section{e. Social Constraints: Rudabeh, Tahmineh, Katayun:}

Up to this point in our analysis we have been expounding the positive aspects of these three women. We have discussed the components of beauty-as-character strength, wisdom, fearlessness, courage, the wholeness and autonomy of character, and their independent decision-making. These characters are by no means insipid; if there is such an impression, it is what the cri tics (such as Noldeke) have created and perpetuated, not the poet, nor the text of the work of art itself. Rudabeh, Tahmineh, and Katayun are not hollow, but rather paradoxical characters whose personal substance is limited by social constraints. It is these constraints to which we now turn our attention.

Rudabeh: despite the strengths of her character, is constantly under the thumb of her father and has to fight for every inch of victory.

Tahmineh: Tahmineh `s limitations are in fact multidimensional. Tahmineh is a female character in a world which is dominated by male, a world in which the female characters are not given a chance to contribute to the outcome of events.

Katayun: Katayun is presented as an active, involved character not only in her personal affairs but also in her involvement with the thematic and intellectual dimensions of the story.

\section{f. Gurdafarid: The Warrior Moman}

Gurdafarid is a minor character in the story of Rustam and Sohrab," a character who enters the story in a single episode and soon disappears; nevertheless, she is one of the most well-known female characters, if not the most famous, in the Shahnameh tradition. She is a highly popular figure among the Shahnameh readers and in the traditional coffee house story telling circles. She is associated with several virtues, the most important of which are her fearlessness, prowess, and above all Patriotism. 
She was a woman on a roundabout, always famous for her war in Andron

Where his name was created because he saw no one inside the war

\title{
g. Sudabeh: THE Shrewd Woman
}

Sudabeh is the queen of King Kavus 1 the stepmother of Prince Siyavush, and a woman whose desires for the young Prince bring them both to a disastrous end. Sudabeh is a major character in the famous "Story of Siyavush" in The Shahnameh.

\author{
Then he told the announcer Kavus \\ That she has a daughter \\ Which is more beautiful than its cedar \\ Officer Musk's shadow on his head \\ Up tall and lashed \\ Her tongue is Chu's dagger on her lips \\ This is one girl in the world \\ Which is dearer than sweet soul \\ He said Sudan Saddle is not the solution \\ Better not be sad today \\ Someone was the prince of the world \\ Brobum will be all of us
}

Is 1 ami-Nudushan adds that in the legendary section of the epic, except Sudabeh, there is no other Shrew.... The woman who has disgraced (the image of) women in 'The Shahnameh is Sudabeh" (1348 H. 119-20). Love for Siyavush is opportunistic and wealth seeking (130).of evil both in sum, Sudabeh is portrayed as a source in the epic itself and in the works of almost all critics.

Islami-Nudushan, for example, observes in his Jame jahan bin ('The Crystal Bal) a comparison of Racine's Phaedra whom he admires and Sudabeh whom he despises in highly ornamented Persian vocabulary:

Through Racine's words we can see a Phaedra who is pale and thin; her beauty is pallid, sickly and majestic for a queen; the desire which it stimulates in a man is delicate, noble rather than sexually inviting. On the contrary, Sudabeh looks vital, fresh, and heal thy; she gets easily pregnant and delivers without any freshness. Her beauty is hot, inviting, and ready; it is not love in sparing. (1355 H. 89)

Apart from being lovable, Sudabeh is also independent-minded. For example she makes up her own mind in her acceptance of Kavus's proposal, and despite her father 1 s reluctance, she decides to marry Kavus and go to Iran with him.

He told her that Sudan is not a saddle. Better not be sad today

Know the father's vote

That has an aggressive sur to the head

He told Kavos that Cain was not voting

Terra itself is no place for Hamavaran

They will grab you in vain

They should not fight with Sur

It is my pleasure to have so many conversations

You will be trampled on

Sudabee didn't believe the speech 
He didn't die until someone died

Be brave and courageous

Remember King Hamavaran

\subsection{Penelope and Nausicaa of the Odyssey}

The Iliad is the story of destroying a home land, devastating families, and enslaving women; the Odyssey is about restoring an invaded homeland, rebuilding a family, and liberating a brave besieged, woman. Women in the Iliad are almost always on the periphery of the story is social structure, hence more often than not they are helpless persons; in the Odyssey they play a relatively more central role, thus they appear more powerful, more dynamic, and more authoritative.

\section{a. Penelope:}

Penelope being one of the most mature women in Homeric epics could have had an impact on many women who listened to their poets. On the subject of moral component $\mathrm{J}$. w. Mackile observes that "Penelope is a believable moral heroine who cannot escape the cultural restrictions on her sex, but whose ingenuity and enduring spirit make her a model of the 'good wife'" (43).

Penelope of the Odyssey represents woman in the center stage of the Homeric epic world. Therefore, due to the central theme of the epic of restoration of home and family, Penelope plays a more vital and dynamic role.

\section{b. Nausicaa:}

Another prominent and praise-worthy woman in the epic is Nausicaa. She demonstrates unusual strength of character and is not at all frightened or shy when she meets a barely clad stranger, Odysseus, in the woods (Odyssey 4, 139). Nausicaa, like Penelope, possesses all the traits of "sapientia" (Odyssey 7, 292), a thoughtfulness. Naus 1caa is an able woman, but also is an auxiliary character, on the periphery, and a tool for the progress of Odysseus.

\section{c. Anticlea :}

Odysseus' mother is another prominent character is Odysseus' mother, who dies due to her prolonged agony for her son, thus fitting the familiar pattern of pathos.

\section{Conclusion}

Female personalities characterized in Homer as well as those in Ferdowsi indicate that the poets grappled with the material they had inherited from their tradition. They did the best the y could with the raw material, they crystalized prowess and wisdom in their ideal characters, they distanced themselves from misogyny, and they reflected the most suitable images that they could handle in the characterization of their female personalities. Two universal poets, one from the East and one from the West, grappled tirelessly with a universal problem which proved to be at least as deep-seated as the poet`s unquestionable genius.

\section{References}

Aalinasab, Zohreh, (2008), Women's Image in Iran's Epic Literature", Boushehr: Dastgheybi Publication. 
Abbasi, Hojjat\& Hossein-Ali Ghobadi, (2010), "The Comparison of Women's Status in Ferdowsi's

Shahnameh and Homer's Iliad and Odyssey", in Mystical Literature And Mythology Magazin,(19), p. 109.

Basirizadeh, Fatemeh. (2019). A Comparative Study of the Psychoanalytical Portrayal of the Women Charactersby Virginia Woolf and Zoya Pirzad. Britain International of Humanatis and Social Sciences Journal, 1-8.

Eslami Nodooshan, Mohammad Ali.(1378). Iran's and Greece's History in Ancient Time. Tehran: Sahami-ye Enteshar.

Eslami Nodooshan, Mohammad Ali. (1393). Jame Jahan bin. Tehran: Ghatre

Raoufzadeh,N. Mohammadhosein,Sh. Zaheri Birgani, Sh. (2019) Analysis of Love, Death, Rebirth and Patriarchy in Two Contemporary Poetess Forough Farrokhzad and Sylvia Plath's Selected Poems. Budapest International Research and Critics Institute-Journal, 56-64. 